\title{
Ugotavljanje sposobnosti prilagoditve listerij na benzalkonijev klorid z določanjem njegove minimalne inhibitorne koncentracije
}

\author{
Monika PODPAC ${ }^{1}$, Barbara JERŠEK ${ }^{1}, 2$
}

Received September 04, 2018; accepted September 13, 2019. Delo je prispelo 04. septembra 2018, sprejeto 13. septembra 2019.

Ugotavljanje sposobnosti prilagoditve listerij na benzalkonijev klorid $\mathrm{z}$ določanjem njegove minimalne inhibitorne koncentracije

Izvleček: Bakterije rodu Listeria v živilski industriji predstavljajo težavo zaradi njihove razširjenosti in dobre sposobnosti preživetja $\mathrm{v}$ neugodnih razmerah. L. monocytogenes (E. Murray et al. 1926) Pirie 1940 je za človeka patogena bakterija, medtem ko je v živilsko-predelovalnem okolju od listerij najpogosteje prisotne nepatogene bakterije vrste $L$. innocua Seeliger (ATCC 33090) Namen dela je bil določiti, ali se listerije lahko prilagodijo na razkužilo benzalkonijev klorid (BAC). Za prilagoditev smo potrebovali natančno določitev protimikrobne aktivnosti BAC. Z metodo razredčevanja v mikrotitrski ploščici (MTP) smo ugotovili minimalno inhibitorno koncentracijo $\left(\mathrm{MIK}_{\mathrm{MTP}}\right)$ BAC za preiskovane seve. Nato smo z rastnimi krivuljami preverili, ali so tako določene koncentracije zares najmanjše koncentracije BAC, ki vplivajo na rast sevov. Ugotovili smo, da imajo inhibitorni učinek že precej manjše koncentracije BAC kot je $\mathrm{MIK}_{\mathrm{MTP}}$, saj so bile minimalne inhibitorne koncentracije določene $\mathrm{z}$ rastnimi krivuljami $\left(\mathrm{MIK}_{\mathrm{RK}}\right)$ le $0,1-0,5 \mathrm{x}$ MIK $_{\text {MTP }}$ Prilagoditev listerij na BAC smo zato izvedli tako, da smo kot začetno koncentracijo BAC uporabili $0,25 \mathrm{x} \mathrm{MIK}_{\mathrm{RK}}$. Rezultati so pokazali, da se je kar $50 \%$ sevov uspelo prilagoditi na BAC, in pri sevu L. monocytogenes ŽM500 je bila ta prilagoditev celo trajna. Metoda razredčevanja v mikrotitrski ploščici je uporabna za približno določitev protimikrobne aktivnosti razkužila, medtem ko je za natančnejšo določitev aktivnosti razkužila potrebno le-to določiti z drugo metodo, kot je npr. štetje kolonij na trdem gojišču.

Ključne besede: razkužila; benzalkonijev klorid; Listeria; metoda razredčevanja v mikrotitrski ploščici; rastna krivulja
Assessing of adaptation ability of Listeria to benzalkonium chloride (BAC) by determination of its minimal inhibitory concentration

Abstract: Bacteria of the genus Listeria pose a problem in the food industry due to their wide distribution and their good survival in adverse conditions. L. monocytogenes (E. Murray et al. 1926) Pirie 1940 is human pathogen, while L. innocua Seeliger (ATCC $33090^{\circ}$ ) as not pathogenic bacteria is the most often found listeria in food production environment. Disinfectants represents an important part of Listeria management in food processing environments and benzalkonium chloride (BAC) is used frequently. The purpose of the work was to determine whether strains of listeria can adapt to BAC. To carry out the adaptation, a precise determination of antibacterial activity of BAC was needed. Firstly minimum inhibitory concentration $\left(\mathrm{MIC}_{\mathrm{MTP}}\right)$ of BAC was determined with broth microdilution method for each Listeria strain. Then, we checked whether $\mathrm{MIC}_{\text {MTP }}$ was indeed the lowest concentration of BAC, which had an influence on growth of strains with growth curves. We found out that growth inhibitory effect $\left(\mathrm{MIC}_{\mathrm{GC}}\right)$ was achieved at concentrations of $\mathrm{BAC}$ that were lower than $\mathrm{MIC}_{\mathrm{MTP}}$ (0.1$0.5 \mathrm{x}$ of $\mathrm{MIC}_{\mathrm{MTP}}$ values). Adaptation of listeria to BAC was therefore performed by using $0.25 \mathrm{x} \mathrm{MIC}_{\mathrm{GC}}$ as the initial $\mathrm{BAC}$ concentration. Results showed that $50 \%$ of the strains were able to adapt to BAC, and in L. monocytogenes ŽM500 this adaptation was even stable. The broth microdilution method was useful for approximate assessment of antimicrobial activity of BAC, while for the more precise determination of disinfectant activity it is necessary to determine it by using another method such as plate count method.

Key words: disinfectants; benzalkonium chloride; Listeria; broth microdilution method; growth curve 


\section{UVOD}

Kvarterne amonijeve spojine (KAC) so pogosto uporabljena razkužila, ki se uporabljajo pri mikrobiološkem obvladovanju znotraj zdravstvenih ustanov, veterinarskih ambulant in živilsko predelovalnih obratov. Posebej primerna so predvsem zaradi majhne korozivnosti in toksičnosti, a so kljub temu zelo protimikrobno učinkovita (Wu in sod., 2015). Med KAC uvrščamo tudi razkužilo benzalkonijev klorid (BAC), ki se kot kationsko površinsko aktivno sredstvo pogosto uporablja za medicinsko dezinfekcijo in sanitacijo $\mathrm{v}$ živilsko predelovalnih okoljih zaradi svoje dvojne, tako hidrofobne kot tudi hidrofilne, narave. Pogosto se dodaja kot biocid v izdelke za osebno nego, kozmetiko in produkte za dezinfekcijo kože (Liu in sod., 2017). Protimikrobno delovanje BAC temelji na spremembi permeabilnosti celične membrane in motenj v naboju celične membrane, kar povzroči izločanje citoplazemske vsebine $\mathrm{v}$ zunanjost celice ter $\mathrm{s}$ tem celično smrt (Arias-Moliz in sod., 2015).

Številne študije kažejo na to, da se bakterije vrste $L$. monocytogenes pri izpostavitvi subinhibitornim koncentracijam BAC lahko prilagodijo na večje koncentracije BAC, vendar mehanizem odpornosti še ni popolnoma raziskan. Predvideva se, da so pri razvoju bakterijske odpornosti proti razkužilom pomembni dejavniki membranske izlivne črpalke, za katere se v literaturi uporabljajo tudi izrazi »sistem transportnih proteinov« in »efluksne črpalke« (Gadea in sod., 2017). Določene študije nakazujejo tudi, da je eden izmed možnih mehanizmov za razvoj odpornosti bakterij vrste L. monocytogenes proti KAS, sprememba sestave maščobnih kislin $\mathrm{v}$ bakterijski membrani (Bisbiroulas in sod., 2011), kar bakterijam omogoča rast v stresnih razmerah. Še več, nekateri strokovnjaki predvidevajo, da bi v teoriji pri prilagoditvi listerij na KAS lahko v bakterijski celici prišlo do aktivacije dveh ali več mehanizmov hkrati, kot so npr. modifikacija strukture in sestave bakterijske membrane, optimizacija tvorbe biofilma, prekomerno izražanje genov, ki kodirajo membranske izlivne črpalke in biorazgradnja razkužila (Gadea in sod., 2017).

Ob pravilni uporabi in primerni koncentraciji so razkužila precej učinkovita pri preprečevanju rasti bakterij. Zaradi različnih razlogov, kot so nepopolno čiščenje delovnih površin, premajhen odmerek uporabljenega razkužila ali zaradi tvorbe biofilma na delovnih površin, pa lahko $\mathrm{v}$ stik $\mathrm{z}$ bakterijami prihajajo tudi $\mathrm{v}$ manjših koncentracijah. $\mathrm{V}$ takih razmerah so bakterije izpostavljene sub-letalnim koncentracijam razkužil, kar lahko vodi do prilagoditve bakterij na razkužila (Soumet in sod., 2016). Zaradi prekomerne uporabe KAC se lahko $\mathrm{v}$ določenih okoljih tako nevede vršijo selektivni pritiski (v smislu delovanja majhnih koncentracij KAC, ki niso dovolj za baktericidno aktivnost), ki lahko prispevajo $\mathrm{k}$ razvoju proti KAC odpornih bakterij. Zaradi vse večjega števila proti protimikrobnim spojinam odpornih bakterij in široke uporabe KAC, je ključnega pomena oceniti, katera metoda je najbolj primerna za določitev protimikrobne aktivnosti KAC. Trenutno ni posebej predpisane metode za določitev protimikrobne aktivnosti KAC. V ta namen se pogosto uporablja metoda razredčevanja $\mathrm{v}$ mikrotitrski ploščici ali metoda razredčevanja $\mathrm{v}$ trdnem gojišču, ki sta standardizirani s strani CLSI (Clinical and Laboratory Standards Institute) (Wu in sod., 2015). Pri metodi razredčevanja $\mathrm{v}$ mikrotitrski plošči se po inkubacijskem obdobju bakterijska rast preverja bodisi $\mathrm{z}$ vizualnim pregledom bodisi s polavtomatskimi ali popolnoma avtomatiziranimi sistemi. Najmanjša koncentracija protimikrobnega sredstva, ki zavre rast bakterij je definirana kot minimalna inhibitorna koncentracija (MIK) (Klančnik in sod., 2010). Prednosti omenjene metode so predvsem $v$ tem, da je metoda enostavna za izvedbo in jo je mogoče enostavno standardizirati pri preiskavah med dvema ali večimi laboratoriji. Kljub temu se $\mathrm{v}$ literaturi pojavljajo študije, ki ugotavljajo relevantnost rezultatov, pridobljenih $\mathrm{z}$ metodo razredčevanja $\mathrm{v}$ mikrotitrski ploščici in katero drugo metodo, ki se danes prav tako pogosto uporablja za določitev protimikrobne aktivnosti preiskovanih spojin. Standardna metoda razredčevanja v mikrotitrski ploščici ima priznano natančnost za en razredčitveni interval, saj metoda za vrednost MIK npr. $1 \mathrm{mg} \mathrm{l}^{-1}$ sprejema vrednosti med 0,5 in $2 \mathrm{mg} \mathrm{l}^{-1}$. Lepe in sod. (2013) so v študiji ugotovili šibko korelacijo med rezultati pridobljeni $\mathrm{z}$ E-testi in metodo razredčevanja $\mathrm{v}$ mikrotirski ploščici, zaradi česar bi bilo zaželeno razviti metodo za še natančnejšo določanje vrednosti MIK. Tudi Klodzinska in sod. (2018) so predpostavili, da bi že samo ob kombiniranju določitve MIK in MBK (mikrobicidne koncentracije) pridobili podrobnejši vpogled $\mathrm{v}$ občutljivost bakterij za protimikrobna sredstva in bolj klinično relevantne podatke.

Namen raziskave je bil določiti, kakšna je zmožnost različnih sevov bakterij rodu Listeria, da se prilagodijo na BAC in hkrati preveriti ali za določitev protimikrobne aktivnosti BAC ustreza uporaba metode razredčevanja $\mathrm{v}$ mikrotitrski ploščici.

\section{MATERIAL IN METODE}

\subsection{SEVI BAKTERIJ RODU LISTERIA IN GOJIŠČA}

V raziskavo smo vključili 10 sevov bakterij rodu $\mathrm{Li}$ steria iz mikrobiološke zbirke Laboratorija za živilsko mikrobiologijo na Oddelku za živilstvo Biotehniške fakul- 
tete (oznaka sevov ŽM). Uporabili smo 5 sevov bakterij vrste Listeria monocytogenes (E. Murray et al. 1926) Pirie 1940) in 5 sevov bakterij vrste L. innocua Seeliger (ATCC 33090 ) (Preglednica 1). Bakterije so bile shranjene pri -20 ${ }^{\circ} \mathrm{C}$ v suspenziji glicerola $(0,15 \mathrm{ml})$ in kulture $(0,85 \mathrm{ml} \mathrm{v}$ tekočem gojišču TSB (angl. Tryptic Soy Broth, Biolife, 4021552, Milano, Italija). Po revitalizaciji smo sev iz gojišča TSB nacepili na selektivno gojišče ALOA (angl. Agar Listeria acc. to Ottaviani \& Agosti, Biolife, 4016052), kjer so po $24 \mathrm{~h}$ pri $37^{\circ} \mathrm{C}$ zrasle modrozelene kolonije, ki so značilne za bakterije vrste L. innocua, in modrozelene kolonije s prosojno cono, ki so značilne za bakterije vrste L. monocytogenes. Po eno kolonijo smo nacepili na gojišče TSA (angl. Tryptic Soy Agar, Biolife, 4021502) in ponovno $24 \mathrm{~h}$ inkubirali pri $37^{\circ} \mathrm{C}$. Pred vsakim eksperimentom smo za pripravo inokuluma $\mathrm{z}$ gojišča TSA vzeli eno kolonijo izbranega seva ter jo prenesli v $4 \mathrm{ml}$ gojišča TSB, vsebino premešali na vrtinčnem mešalniku in 4 ure inkubirali pri $37^{\circ} \mathrm{C}$ na stresalniku ( 75 obratov/ minuto). Predvidevali smo, da se je v tem času kultura namnožila do koncentracije $10^{8} \mathrm{KE}$ (kolonijskih enot) $\mathrm{ml}^{-1}$. Za nadaljnje delo smo $150 \mu$ lako pripravljene kulture prenesli $\mathrm{v} 10 \mathrm{ml}$ gojišča TSB ter točno koncentracijo celic določili z metodo štetja kolonij na gojišču TSA.

\subsection{BENZALKONIJEV KLORID}

Pri raziskovalnem delu smo uporabili benzalkonijev klorid (BAC, ang. Benzalkonium chloride, Sigma Aldrich, B6295, Saint Louis, ZDA). Pri pripravi delovne raztopine za določitev protimikrobne aktivnosti BAC za seve L. monocytogenes smo $10 \mathrm{mg}$ BAC raztopili $\mathrm{v} 1 \mathrm{ml}$ gojišča TSB ter redčenje $\mathrm{z}$ gojiščem TSB nadaljevali do koncentracije $100 \mu \mathrm{g} \mathrm{ml} \mathrm{m}^{-1}$. Za določitev protimikrobne aktivnosti BAC za seve $L$. innocua smo na enak način pripravili delovno raztopino $\mathrm{BAC}\left(5 \mathrm{mg} \mathrm{ml}^{-1}\right)$ ter redčenje $\mathrm{z}$ gojiščem TSB nadaljevali do koncentracije $500 \mu \mathrm{g} \mathrm{ml}^{-1}$ saj so podatki iz literature nakazovali, da je minimalna inhibitorna koncentracija (MIK) BAC za seve L. innocua nekoliko večja (Korsak in Szuplewska, 2016).

\subsection{METODA RAZREDČEVANJA V MIKROTI- TRSKI PLOŠČICI}

Za določitev minimalne inhibitorne koncentracije (MIK) razkužila BAC smo uporabili metodo razredčevanja v mikrotitrski ploščici (Klančnik in sod., 2010) in to koncentracijo označili kot $\mathrm{MIK}_{\mathrm{MTP}}$. Po $24 \mathrm{~h}$ inkubaciji pri $37^{\circ} \mathrm{C}$ smo v vse luknjice mikrotitrske ploščice, ki so vsebovale preiskovan sev listerij in različne koncentracije BAC, dodali $10 \mu$ reagenta INT (2-p-iodofenil-3-p- -nitrofenil-5-fentil tetrazolijev klorid, $2 \mathrm{mg} \mathrm{ml}^{-1}$ Sigma Aldrich, 18377-56, Saint Luis, ZDA) ter mikrotitrsko ploščico 1 minuto stresali na stresalniku (100 obratov/ minuto) in jo ponovno 20 minut inkubirali pri $37^{\circ} \mathrm{C}$. Vrednost $\mathrm{MIK}_{\mathrm{MTP}}$ smo določili vizualno glede na obarvanost suspenzije v posamezni luknjici, pri čemer je bila prva neobarvana luknjica določena kot $\mathrm{MIK}_{\mathrm{MTP}} \mathrm{BAC}$, saj je to pomenilo, da ni več metabolno aktivnih bakterijskih celic, ki bi INT lahko reducirale v rdeč formazan (Klančnik in sod., 2010). MIK ${ }_{\text {MTP }}$ smo definirali kot najmanjšo koncentracijo, ki zavira vidno rast testnega seva bakterij (Burt, 2004). Po določitvi vrednosti $\mathrm{MIK}_{\mathrm{MTP}}$ smo pri tej koncentraciji BAC določili število preživelih bakterij $\mathrm{z}$ metodo štetja kolonij na trdem gojišču TSA. Vse preiskave $\mathrm{z}$ metodo razredčevanja $\mathrm{v}$ mikrotitrski ploščici smo izvedli v 2 ali 3 paralelkah.

\subsection{RASTNA KRIVULJA}

$\mathrm{Z}$ rastno krivuljo smo preverjali, ali je koncentracija BAC določena $\mathrm{z}$ metodo razredčevanja $\mathrm{v}$ mikrotitrski ploščici $\left(\mathrm{MIK}_{\mathrm{MTP}}\right)$ dejansko najmanjša koncentracija $\mathrm{BAC}$, ki zmanjša rast posameznega seva listerij. Rastno krivuljo smo določili tako, da smo v epruveto z $8,5 \mathrm{ml}$ gojišča TSB dodali $1 \mathrm{ml}$ delovne raztopine razkužila $s$ tako koncentracijo, da je bila končna koncentracija razkužila v $10 \mathrm{ml}$ raztopine enaka določeni $\mathrm{MIK}_{\mathrm{MTP}} \mathrm{BAC}$, in $0,5 \mathrm{ml}$ inokuluma testnega seva listerij. Vzporedno smo $\mathrm{v}$ drugo epruveto z 9,5 $\mathrm{ml}$ TSB dodali $0,5 \mathrm{ml}$ inokuluma testnega seva listerij (kontrolni vzorec). Vzorce smo nato $24 \mathrm{~h}$ inkubirali pri $37^{\circ} \mathrm{C}$. Vzorčili smo v času 0,4 in 24 $\mathrm{h}$ ter določili število listerij, ki so rasle $\mathrm{v}$ gojišču TSB z dodanim BAC, in število listerij, ki so rasle v gojišču TSB brez dodanega BAC $\mathrm{z}$ metodo štetja kolonij na trdem gojišču TSA. S pridobljeni podatki smo izrisali grafe, ki so ponazarjali rast posameznih sevov listerij pri MIK $_{\mathrm{MTP}}$ BAC. Rastne krivulje smo določili tudi pri manjših koncentracijah BAC, kot je bila določena $\mathrm{MIK}_{\mathrm{MTP}}$. Minimalno inhibitorno koncentracijo BAC smo nato določili iz rastnih krivulj in jo označili kot $\mathrm{MIK}_{\mathrm{RK}}$ pri tisti najmanjši koncentraciji BAC, kjer je bila statistično značilna razlika (Sekcija 2.5) med rastjo posameznega seva v gojišču TSB $\mathrm{z}$ dodanim BAC $\mathrm{v}$ gojišču TSB brez dodanega BAC. Vse rastne krivulje smo določili v najmanj dveh paralelkah.

\subsection{STATISTIČNA OBDELAVA}

Rezultate, pridobljene $\mathrm{z}$ rastnimi krivuljami, smo primerjali $s$ testom ANOVA (Microsoft Excel). Predpostavili smo, da velja ničelna hipoteza $\left(\mathrm{H}_{0}\right)$ in izbrali 0,05 za stopnjo značilnosti $a$. Iz vzorca smo izračunali 
testno statistiko in glede na to, $v$ katero območje je vrednost padla, ovrednotili rezultate. V kolikor je bila verjetnost $p>0,05$, smo ničelno domnevo obdržali, kar pomeni, da rezultati niso bili statistično značilno različni. $\mathrm{V}$ nasprotnem primeru, ko je bila $\mathrm{p}<0,05$, smo ničelno domnevo zavrnili $\mathrm{v}$ korist alternativne domneve $\left(\mathrm{H}_{1}\right)$, kar je pomenilo, da so rezultati statistično značilno različni (Košmelj, 2007).

\subsection{PRILAGODITEV LISTERIJ NA BENZALKO- NIJEV KLORID}

Prilagoditev posameznega seva listerij na BAC smo izvajali v 2 paralelkah in vzporedno $\mathrm{v} 2$ paralelkah preverjali rast istega seva bakterij $\mathrm{v}$ samem gojišču TSB (kontrolna vzorca). $150 \mu$ l pripravljene prekonočne kulture posameznega seva listerij smo prenesli v $10 \mathrm{ml}$ tekočega gojišča TSB. $150 \mu \mathrm{l}$ tako pripravljenega inokuluma smo aseptično prenesli $\mathrm{v}$ epruveto, kjer je bilo $9 \mathrm{ml}$ gojišča TSB in dodali 1 ml ustrezno razredčene delovne raztopine razkužila BAC. Razredčitve delovne raztopine BAC smo izvedli glede na predhodno določene vrednosti MIK $_{\mathrm{RK}}$ tako, da smo prilagoditev posameznega seva listerij začeli pri $0,25 \mathrm{x} \mathrm{MIK}_{\mathrm{RK}}$. Seve smo postopoma izpostavljali naraščajočim se koncentracijam BAC vse do $16 \mathrm{x}$ MI$\mathrm{K}_{\mathrm{RK}}$ oz. do koncentracije, pri kateri se je rast bakterij ustavila. Rast bakterij smo pri manjših koncentracijah $\operatorname{BAC}\left(0,25 \mathrm{x}-2 \mathrm{x} \mathrm{MIK}_{\mathrm{RK}}\right)$ določili s pojavom motnosti gojišča TSB v epruveti, ki je vsebovala dodatek BAC v primerjavi s kontrolno epruveto, ki je vsebovala gojišče TSB brez dodanega BAC. Pri večjih koncentracijah BAC $\left(>\mathrm{MIK}_{\mathrm{RK}}\right)$ smo rast listerij določili z metodo štetja kolonij na trdnem gojišču, saj motnost ni bila več očitna. V primerih, ko ni bilo zaznane bakterijske rasti, smo vzorce inkubirali do sedem dni ter vsak dan preverjali, če je prišlo do kakšne spremembe v koncentraciji listerij. V kolikor po sedmih dneh ni bilo zaznane rasti, smo prilagoditev zaključili. Pri kontrolnem vzorcu smo v $10 \mathrm{ml}$ TSB dodali $150 \mu$ l razredčene prekonočne kulture izbranega seva in sev inkubirali $\mathrm{v}$ enakih razmerah kot sev, ki smo ga prilagajali na BAC.

\section{REZULTATI IN RAZPRAVA}

Glavni namen raziskave je bil določiti sposobnost prilagoditve različnih sevov listerij za benzalkonijev klorid. Prvi korak za nadaljnji poskus prilagoditve je bil ugotoviti, katera je najmanjša koncentracija BAC, ki ima inhibitorni učinek za rast posameznega seva.

\subsection{DOLOČITEV KONCENTRACIJE BENZALKO- NIJEVEGA KLORIDA ZA RAZLIČNE SEVE LISTERIJ}

Za izvedbo prilagoditve smo za posamezen sev najprej določili protibakterijsko učinkovitost BAC tako, da smo določili minimalne inhibitorne koncentracije $\mathrm{z}$ metodo razredčevanja $\mathrm{v}$ mikrotitrski ploščici $\left(\mathrm{MIK}_{\mathrm{MTP}}\right)$. Ker smo ugotovili, da so te koncentracije BAC zelo velike in da lahko delujejo že baktericidno (Preglednica 1), smo natančneje določili minimalne inhibitorne koncentracije iz rastnih krivulj $\left(\mathrm{MIK}_{\mathrm{RK}}\right)$, pri katerih smo rast posameznega seva listerij spremljali pri različnih manjših koncentracijah BAC, kot je bila določena $\mathrm{MIK}_{\mathrm{MTP}}$. Rezultati so pokazali, da se $\mathrm{MIK}_{\mathrm{MTP}}$ in $\mathrm{MIK}_{\mathrm{RK}}$ med seboj zelo razlikujejo (Preglednica 1). To lahko pojasnimo s tem, da gre pri metodi razredčevanja $\mathrm{v}$ mikrotitrski ploščici za »ohlapno«, manj točno metodo, s katero testiramo zelo široko koncentracijsko območje razkužila, kjer je rezultat le približna minimalna inhibitorna koncentracija. Poleg tega $\mathrm{z}$ reagentom INT ne moremo določiti števila preživelih bakterij, ampak le ugotovimo pri kateri koncentraciji je bakterij dovolj, da zaznamo spremembo v barvi gojišča zaradi redukcije barvila INT (Berridge in sod., 2005). Na primer pri sevu L. innocua ŽM39 je bila MIK ${ }_{\text {MTP }}$ BAC $7,81 \mu \mathrm{g} \mathrm{ml}^{-1}$, medtem ko smo $\mathrm{z}$ rastno krivuljo določili, da pride do statistično značilnega zmanjšanja rasti že pri $1,95 \mu \mathrm{g} \mathrm{ml} \mathrm{m}^{-1} \mathrm{BAC}\left(\mathrm{MIK}_{\mathrm{RK}}\right)$ in zato smo to koncentracijo upoštevali kot tisto, kjer se rast tega seva bakterij že zmanjša. Analogno smo za vse druge seve listerij določili, da so $\mathrm{MIK}_{\mathrm{RK}}$ od $2 \mathrm{x}$ do $8 \mathrm{x}$ manjše od $\mathrm{MIK}_{\mathrm{MTP}}$ (Preglednica $1)$.

Rezultati $\mathrm{MIK}_{\mathrm{MPT}}$ iz preglednice 1 so primerljivi $\mathrm{z}$ rezultati, ki so jih pokazali Soumet in sodelavci (2005). Pri rezultatih dobljenih $\mathrm{z}$ metodo razredčevanja $\mathrm{v}$ mikrotitrski ploščici so ugotovili, da je vrednost MIK za BAC pri bakterijah vrste $L$. monocytogenes $\mathrm{v}$ območju med 1,87 in $15 \mu \mathrm{g} \mathrm{ml} \mathrm{m}^{-1}$, pri čemer so jo pri 88 sevih od 254 preiskovanih določili pri koncentraciji $3,75 \mu \mathrm{g} \mathrm{ml} \mathrm{m}^{-1}$. Tudi vrednosti $\mathrm{MIK}_{\mathrm{MPT}}$ izbranih sevov bakterij vrste $L$. innocua se v našem primeru skladajo s podatki iz literature. Korsak in Szuplewska (2016) sta pri 90 \% preiskovanih sevov bakterij vrste $L$. innocua $\mathrm{z}$ uporabo metode razredčevanja v mikrotitrski ploščici določili vrednost MIK za BAC $5 \mu \mathrm{g} \mathrm{ml}^{-1}$, pri čemer se je območje MIK za preiskovane seve bakterij vrste L. innocua gibalo med 2,5 in $40 \mu \mathrm{g} \mathrm{ml}^{-1}$, kar je v skladu z našimi rezultati $\mathrm{MIK}_{\mathrm{MPT}}$ (Preglednica 1).

\subsection{PRILAGODITEV LISTERIJ NA BENZALKONI- JEV KLORID}

S prilagoditvijo listerij na BAC smo začeli pri zelo 
Tabela 1: Določitev minimalne inhibitorne koncentracije benzalkonijevega klorida $\mathrm{z}$ metodo razredčevanja $\mathrm{v}$ mikrotitrski ploščici in rastno krivuljo za seve bakterij rodu Listeria

Table 1: Determination of minimum inhibitory concentration of benzalkonium chloride by microdilution method and growth curve for Listeria strains

\begin{tabular}{|c|c|c|c|c|c|c|c|c|c|}
\hline \multirow[b]{3}{*}{ Sev } & \multicolumn{2}{|c|}{$\begin{array}{l}\text { Metoda razredčevanja } \\
\text { v mikrotitrski ploščici }\end{array}$} & \multicolumn{7}{|c|}{ Rastna krivulja } \\
\hline & \multirow[t]{2}{*}{$\begin{array}{l}\mathrm{MIK}_{\mathrm{MTP}} \\
\left(\mu \mathrm{g} \mathrm{ml}^{-1}\right)\end{array}$} & \multirow[t]{2}{*}{$\begin{array}{l}\mathrm{N}_{\mathrm{MTP}} \\
\left(\mathrm{KE} \mathrm{ml} \mathrm{m}^{-1}\right)\end{array}$} & \multicolumn{2}{|c|}{$0,5 \times \mathrm{MIK}_{\mathrm{MTP}}$} & \multicolumn{2}{|c|}{$0,25 \times \mathrm{MIK}_{\mathrm{MTP}}$} & \multicolumn{2}{|c|}{$0,125 \times \mathrm{MIK}_{\mathrm{MTP}}$} & \multirow[t]{2}{*}{$\begin{array}{l}\mathrm{MIK}_{\mathrm{RK}} \\
\left(\mu \mathrm{g} \mathrm{m} l^{-1}\right)\end{array}$} \\
\hline & & & $\begin{array}{l}\mathrm{C} \\
\left(\mu \mathrm{g} \mathrm{ml}^{-1}\right)\end{array}$ & 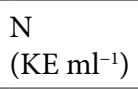 & $\begin{array}{l}\mathrm{C} \\
\left(\mu \mathrm{g} \mathrm{ml}^{-1}\right)\end{array}$ & $\begin{array}{l}\mathrm{N} \\
\left(\mathrm{KE} \mathrm{ml}^{-1}\right)\end{array}$ & $\begin{array}{l}\mathrm{C} \\
\left(\mu \mathrm{g} \mathrm{ml} \mathrm{I}^{-1}\right)\end{array}$ & $\begin{array}{l}\mathrm{N} \\
\left(\mathrm{KE} \mathrm{m} \mathrm{m}^{-1}\right)\end{array}$ & \\
\hline L. innocua ŽM39 & 7,81 & $3,5 \times 10^{3}$ & 3,91 & $<10$ & 1,95 & $2,3 \times 10^{8}$ & l & l & 1,95 \\
\hline L. innocua ŽM40 & 7,81 & $1,7 \times 10^{2}$ & 3,91 & $<10$ & 1,95 & $<10$ & 0,98 & $1,0 \times 10^{9}$ & 0,98 \\
\hline L. innocua ŽM41 & 7,81 & $5,2 \times 10^{2}$ & 3,91 & $<10$ & 1,95 & $<10$ & 0,98 & $4,2 \times 10^{7}$ & 0,98 \\
\hline L. innocua ŽM43 & 7,81 & $1,6 \times 10^{3}$ & 3,91 & $<10$ & 1,95 & $2,6 \times 10^{8}$ & l & l & 1,95 \\
\hline L. innocua ŽM68 & 7,81 & $6,0 \times 10^{1}$ & 3,91 & $<10$ & 1,95 & $2,6 \times 10^{2}$ & 0,98 & $4,0 \times 10^{7}$ & 0,98 \\
\hline L. monocytogenes ŽM51 & 6,25 & $<10$ & 3,13 & $1,0 \times 10^{5}$ & 1,56 & I & I & l & 3,13 \\
\hline L. monocytogenes ŽM58 & 6,25 & $<10$ & 3,13 & $6,6 \times 10^{7}$ & 1,56 & I & I & / & 3,13 \\
\hline L. monocytogenes ŽM69 & 12,5 & $<10$ & 6,25 & $<10$ & 3,13 & $1,7 \times 10^{7}$ & l & I & 3,13 \\
\hline L. monocytogenes ŽM500 & 6,25 & $<10$ & 3,13 & $7,0 \times 10^{1}$ & 1,56 & $2,6 \times 10^{6}$ & l & l & 1,56 \\
\hline L. monocytogenes ŽM520 & 12,5 & $<10$ & 6,25 & $<10$ & 3,13 & $9,3 \times 10^{5}$ & 1 & 1 & 3,13 \\
\hline
\end{tabular}

Sev

Legenda: MIK MTP: MIK, dobljena z metodo razredčevanja v mikrotitrski ploščici; NMTP: število bakterij, določeno pri metodi razredčevanja v mikrotitrski ploščici; N: število bakterij, določeno pri rastni krivulji; KE: kolonijska enota; C: koncentracija benzalkonijevega klorida, uporabljena pri rastni krivulji; poudarjena pisava: $\mathrm{C}$ in $\mathrm{N}$, določena kot tista koncentracija $(\mathrm{C})$, pri kateri je število bakterij $(\mathrm{N})$ manjše kot pri kontrolnem vzorcu, kjer so bakterije rasle $\mathrm{v}$ gojišču brez benzalkonijevega klorida $(p<0,05)$, pri tej koncentraciji smo C definirali kot minimalno inhibitorno koncentracijo, pridobljeno iz rastne krivulje: MIK RK: dosežena MIK

majhni koncentraciji razkužila, to je pri 0,25 x $\mathrm{MIK}_{\mathrm{RK}}$, ki smo jo določili glede na podatke iz rastnih krivulj (Preglednica 1). S to izbiro majhne začetne koncentracije BAC smo listerijam omogočili postopno in tudi časovno dovolj dolgo prilagoditev.

Trije preiskovani sevi L. innocua so se uspeli prilagoditi na $8 \times \mathrm{MIK}_{\mathrm{RK}}\left(7,84 \mu \mathrm{g} \mathrm{ml}^{-1}\right)$, saj pri $16 \times \mathrm{MIK}_{\mathrm{RK}}$ $\left(15,6 \mu \mathrm{g} \mathrm{ml}^{-1}\right)$ ni bilo mogoče zaznati preživelih listerij $\mathrm{Z}$ metodo štetja kolonij na trdnem gojišču $(\mathrm{N}<10 \mathrm{KE}$ $\mathrm{ml}^{-1}$ ), zato smo adaptacijo zaključili (Preglednica 2). Do prilagoditve na $8 \times \mathrm{MIK}_{\mathrm{RK}}\left(7,84 \mu \mathrm{g} \mathrm{ml}^{-1}\right) \mathrm{BAC}$ je prišlo tudi pri treh sevih L. innocua ŽM40, L. innocua ŽM41 in L. innocua ŽM68. V primeru sevov bakterij vrste $L$. monocytogenes sta se dva seva, L. monocytogenes ŽM500 in L. monocytogenes ŽM520, uspela prilagoditi na večje koncentracije BAC. Rast seva L. monocytogenes ŽM500 je bila pri naraščajočih koncentracijah BAC še vedno zaznana pri $8 \times \mathrm{MIK}_{\mathrm{RK}}\left(12,5 \mu \mathrm{g} \mathrm{ml}^{-1}\right)$, medtem, ko se je pri $16 \times \mathrm{MIK}_{\mathrm{RK}}\left(25 \mu \mathrm{g} \mathrm{ml}^{-1}\right)$ prilagoditev ustavila. $\mathrm{Za}$ razliko od rasti seva $L$. monocytogenes ŽM500 se je rast seva L. monocytogenes ŽM520 ustavila že pri 4 x MIK $_{\mathrm{RK}}$ $\left(12,5 \mu \mathrm{g} \mathrm{ml}^{-1}\right)$. Sev L. monocytogenes ŽM500 se je prilagodil na $8 \times \mathrm{MIK}_{\mathrm{RK}}\left(12,5 \mu \mathrm{g} \mathrm{ml}^{-1}\right)$ in sev L. monocytogenes ŽM520 na $4 \mathrm{x}$ vrednost MIK $_{\mathrm{RK}}\left(12,5 \mu \mathrm{g} \mathrm{ml}^{-1}\right)$ (Preglednica 2). Do prilagoditve ni prišlo pri dveh sevih $L$. innocua
ŽM39 ter L. innocua ŽM43 in treh sevih L. monocytogenes ŽM51, L. monocytogenes ŽM58 ter L. monocytogenes ŽM69.

Podobne rezultate so dobili tudi Aase in sodelavci (2000), ki so ugotovili, da so se sevi, kljub različnim začetnim MIK, med prilagajanjem uspeli prilagoditi na približno enake končne koncentracije BAC. Tudi naši rezultati so pokazali, da sta se tako sev L. monocytogenes ŽM500 kot sev L. monocytogenes ŽM520 uspela prilagoditi na $12,5 \mu \mathrm{g} \mathrm{BAC} \mathrm{ml}^{-1}$, kljub temu, da so rezultati rastne krivulje pokazali, da je $\mathrm{MIK}_{\mathrm{RK}}$ seva L. monocytogenes ŽM500 za polovico manjša od $\mathrm{MIK}_{\mathrm{RK}}$ seva L. monocytogenes ŽM520. Pri tem je potrebno omeniti, da se končna koncentracija prilagojenih sevov v naši raziskavi razlikuje od koncentracij raziskave Aase in sod. (2000), saj so se sevi L. monocytogenes $\mathrm{v}$ njihovi raziskavi prilagodili le na $7 \mu \mathrm{g} \mathrm{ml}^{-1}$. Podobno so ugotovili tudi To in sod. (2002), ki so pokazali, da je MIK prilagojenih sevov ostala $\mathrm{v}$ območju med 5-8 $\mu \mathrm{g} \mathrm{ml}^{-1}$. Tudi v primeru prilagoditve bakterij vrste L. innocua se je izkazalo, da so se sevi uspeli prilagoditi na enake koncentracije BAC, pri čemer je bila končna koncentracija prilagoditve $7,84 \mu \mathrm{g} \mathrm{BAC} \mathrm{ml}{ }^{-1}$ (Preglednica 2), kar je sicer manjša koncentracija kot v primeru bakterij vrste L. monocytogenes (Preglednica 2). $\mathrm{V}$ nam dostopni literaturi primerljivih podatkov o prila- 
Tabela 2: Prilagoditev sevov bakterij rodu Listeria na povečane koncentracije benzalkonijevega klorida Table 2: Adaptation of Listeria strains to increased concentrations of benzalkonium chloride

\begin{tabular}{|c|c|c|c|c|c|c|c|}
\hline \multirow[b]{2}{*}{ Sev } & \multicolumn{7}{|l|}{$\mathrm{C}\left(\mu \mathrm{g} \mathrm{ml}^{-1}\right)$} \\
\hline & $0,25 \times \mathrm{MIK}_{\mathrm{RK}}$ & $0,5 \times \mathrm{MIK}_{\mathrm{RK}}$ & $1 \mathrm{x} \mathrm{MIK}_{\mathrm{RK}}$ & $2 \times \mathrm{MIK}_{\mathrm{RK}}$ & $4 \times \mathrm{MIK}_{\mathrm{RK}}$ & $8 \times \mathrm{MIK}_{\mathrm{RK}}$ & $16 \times \mathrm{MIK}_{\mathrm{RK}}$ \\
\hline L. innocua ŽM39 & 0,49 & 0,98 & 1,96 & 3,92 & 7,84 & 15,68 & 31,36 \\
\hline L. innocua ŽM40 & 0,24 & 0,49 & 0,98 & 1,96 & 3,92 & 7,84 & 15,68 \\
\hline L. innocua ŽM41 & 0,24 & 0,49 & 0,98 & 1,96 & 3,92 & 7,84 & 15,68 \\
\hline L. innocua ŽM43 & 0,49 & 0,98 & 1,96 & 3,92 & 7,84 & 15,68 & 31,36 \\
\hline L. innocua ŽM68 & 0,24 & 0,49 & 0,98 & 1,96 & 3,92 & 7,84 & 15,68 \\
\hline L. monocytogenes ŽM51 & 0,78 & 1,56 & 3,12 & 6,25 & 12,5 & 25 & 50 \\
\hline L. monocytogenes ŽM58 & 0,78 & 1,56 & 3,12 & 6,25 & 12,5 & 25 & 50 \\
\hline L. monocytogenes ŽM69 & 0,78 & 1,56 & 3,12 & 6,25 & 12,5 & 25 & 50 \\
\hline L. monocytogenes ŽM500 & 0,39 & 0,78 & 1,56 & 3,12 & 6,25 & 12,5 & 25 \\
\hline L. monocytogenes ŽM520 & 0,78 & 1,56 & 3,12 & 6,25 & 12,5 & 25 & 50 \\
\hline
\end{tabular}

Legenda: MIK: minimalna inhibitorna koncentracija; MIKRK: MIK, dobljena z rastno krivuljo; poudarjeno zapisane vrednosti: največja koncentracija benzalkonijevega klorida, do katere se je sev prilagodil

goditvi bakterij vrste L. innocua na BAC ali sorodno KAS nismo zasledili.

\subsection{STABILNOST PRILAGODITVE LISTERIJ NA BENZALKONIJEV KLORID}

Po prilagoditvi petih sevov bakterij rodu Listeria (Preglednica 2) smo preverili, ali je le-ta trajna ali začasna. Seve smo sedemkrat zapored precepili na trdno gojišče TSA brez dodanega BAC (Aase in sod., 2000) in ponovno določili minimalno inhibitorno koncentracijo BAC za vsak sev in vsako izmed precepitev $\mathrm{z}$ metodo razredčevanja $\mathrm{v}$ mikrotitrski ploščici $\left(\mathrm{MIK}_{\mathrm{MTP}}\right)$. Že pri prvi precepitvi se je izkazalo, da se $\mathrm{MIK}_{\mathrm{MTP}}$ ni ujemala s koncentracijo BAC, na katero so se sevi prilagodili. Ugotovili smo namreč, da se je $\mathrm{MIK}_{\mathrm{MTP}}$ prilagojenih sevov, določena $\mathrm{z}$ metodo razredčevanja $\mathrm{v}$ mikrotitrski ploščici po adaptaciji povečala skladno faktorjem prilagoditve in je bila 4-8 x MIK vrednosti, ki je bila sprva določena $\mathrm{z}$ metodo razredčevanja $\mathrm{v}$ mikrotitrski ploščici (Preglednica 3). Z dobljenimi rezultati smo tako potrdili, da se $\mathrm{MIK}_{\mathrm{MTP}}$, določena $\mathrm{z}$ metodo razredčevanja $\mathrm{v}$ mikrotitrski ploščici razlikuje od dejanske MIK določene z rastno krivuljo $\mathrm{MIK}_{\mathrm{RK}}$. V nadaljevanju smo preverjali vrednosti MIK $_{\text {MTP }}$ prilagojenih sevov bakterij rodu Listeria za nadaljnjih sedem precepitev. Pri štirih izmed petih prilagojenih sevov bakterij rodu Listeria je $\mathrm{MIK}_{\mathrm{MTP}}$ s precepitvami na trdno gojišče TSA pričela upadati, a je še vedno ostajala večja pri vseh štirih sevih bakterij rodu Listeria $\left(25 \mu \mathrm{g} \mathrm{ml}^{-1}-50 \mu \mathrm{g} \mathrm{ml}^{-1}\right)$ glede na dejansko koncentracijo benzalkonijevega klorida, na katero smo prilagodili seve $\left(6,25 \mu \mathrm{g} \mathrm{ml}^{-1}-12,5 \mu \mathrm{g} \mathrm{ml}^{-1}\right)$.
Od petih prilagojenih sevov listerij je bil sev L. monocytogenes ŽM500 edini, pri katerem je MIK' po sedmih zaporednih precepljanjih ostala nespremenjena. Sklepali smo, da je pri prilagoditvi v primeru štirih sevov bakterij rodu Listeria prišlo do razvoja prilagojenih sevov z začasno povečano odpornostjo na benzalkonijev klorid, medtem ko je v primeru seva L. monocytogenes ŽM500 pri adaptaciji prišlo do razvoja odpornega seva proti benzalkonijevemu kloridu.

\section{SKLEPI}

Metoda razredčevanja $\mathrm{v}$ mikrotitrski ploščici je uporabna za približno določitev protimikrobne aktivnosti razkužila, medtem ko je za natančnejšo določitev aktivnosti razkužila potrebno le-to določiti z drugo metodo (npr. določitev števila preživelih bakterij z metodo štetja kolonij na trdnem gojišču). Predvidevamo namreč, da se pri prilagoditvi na večje koncentracije benzalkonijevega klorida ne bi prilagodilo tolikšno število sevov listerij, če bi prilagoditev pričeli s tako velikimi koncentracijami, kot smo jih določili z metodo razredčevanja v mikrotitrski ploščici. Prikazani rezultati kažejo na sicer sprejemljivo rutinsko uporabo metode razredčevanja $\mathrm{v}$ mikrotitrski ploščici, ki jo je za natančnejše študije potrebno nujno kombinirati $z$ drugimi metodami.

\section{$5 \quad$ VIRI}

Aase, B., Sundheim, G., Langsrud, S., \& Rorvik, L.M. (2000). Occurrence of and a possible mechanism for resistance to 
Tabela 3: Stabilnost prilagoditve na benzalkonijev klorid prilagojenih sevov bakterij rodu Listeria Table 3: Stability of adaptation to benzalkonium chloride-adapted Listeria strains

\begin{tabular}{|c|c|c|c|c|c|c|c|}
\hline & & & $\mathrm{BAC}\left(\mu \mathrm{g} \mathrm{ml}^{-1}\right)$ & & & & \\
\hline & & & $\begin{array}{l}\text { L. monocytogenes } L \\
\text { ŽM500 }\end{array}$ & $\begin{array}{l}\text { L. monocytogenes } I \\
\text { ŽM520 }\end{array}$ & $\begin{array}{l}\text { L. innocua } \\
\text { ŽM40 }\end{array}$ & $\begin{array}{l}\text { L. innocua } \\
\text { ŽM41 }\end{array}$ & $\begin{array}{l}\text { L. innocua } \\
\text { ŽM68 }\end{array}$ \\
\hline & & $\mathrm{MIK}_{\mathrm{MTP}}$ & 6,25 & 12,5 & 7,81 & 7,81 & 7,81 \\
\hline & & $\mathrm{MIK}_{\mathrm{RK}}$ & 1,56 & 3,125 & 0,98 & 0,98 & 0,98 \\
\hline Neprilagojen sev & & $\mathrm{n}-\mathrm{MIK}_{\mathrm{RK}}$ & $8 x$ & $4 \mathrm{x}$ & $8 \mathrm{x}$ & $8 \mathrm{x}$ & $8 \mathrm{x}$ \\
\hline & 2 prec. & $\mathrm{MIK}_{\mathrm{MTP}}$ & 50 & 100 & 62,5 & 62,5 & 62,5 \\
\hline & 3 prec. & $\mathrm{MIK}_{\mathrm{MTP}}$ & 50 & 100 & 62,5 & 62,5 & 62,5 \\
\hline $\overrightarrow{\&}$ & 4 prec. & $\mathrm{MIK}_{\mathrm{MTP}}$ & l & l & 62,5 & 31,25 & 62,5 \\
\hline$\frac{0}{2}$ & 5 prec. & $\mathrm{MIK}_{\mathrm{MTP}}$ & 50 & 25 & 62,5 & 31,25 & 62,5 \\
\hline 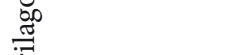 & 6 prec. & $\mathrm{MIK}_{\mathrm{MTP}}$ & 50 & 25 & l & / & / \\
\hline$=$ & 7 prec. & MIK $_{\text {MTP }}$ & 50 & 25 & 31,25 & 31,25 & 31,25 \\
\hline
\end{tabular}

Legenda: BAC: benzalkonijev klorid, MIKMTP: minimalna inhibitorna koncentracija BAC, določena z metodo razredčevanja v mikrotitrski ploščici, MIKRK: minimalna inhibitorna koncentracija BAC, določena z rastno krivuljo; n-MIKRK: n-kratnik vrednosti MIKRK, določene z rastno krivuljo, na katero so se prilagojeni sevi prilagodili, prec.: precepitev; /: ni določeno, precepitev seva na TSA; odebeljena pisava: razvoj seva, odpornega proti BAC

a quaternary ammonium compound in Listeria monocytogenes. International Journal of Food Microbiology, 62(1-2), 57-63. https://doi.org/10.1016/S0168-1605(00)00357-3

Arias-Moliz, M.T., Ruiz-Linares, M., Cassar, G., Ferrer-Luque, C.M., Baca, P., Ordinola-Zapata, R., \& Camilleri J. (2015). The effect of benzalkonium chloride additions to AH Plus sealer. Antimicrobial, physical and chemical properties. Journal of Dentistry, 43(7), 846-854. https://doi.org/10.1016/j. jdent.2015.05.003

Berridge, M. V., Hers,t P. M., \& Tan, A.S. (2005). Tetrazolium dyes as tools in cell biology: New insights into their cellular reduction. Biotechnology Annual Review, 11, 127-152. https://doi.org/10.1016/S1387-2656(05)11004-7

Bisbiroulas, P., Psylou, M., Iliopoulou, I., Diakogiannis, I., Berberi, A., \& Mastronicolis S.K. (2011). Adaptational changes in cellular phospholipids and fatty acid composition of the food pathogen Listeria monocytogenes as a stress response to disinfectant sanitizer benzalkonium chloride. Letters in Applied Microbiology, 52, 3, 275-280. https://doi. org/10.1111/j.1472-765X.2010.02995.x

Burt, S. (2004). Essential oils: their antibacterial properties and potential applications in foods - a review. International Journal of Food Microbiology, 94(3), 223-253. https://doi. org/10.1016/j.ijfoodmicro.2004.03.022

Gadea, R., Fuentes, M.A.F., Pulido, R.P., Galvez, A., \& Ortega, E. (2017). Effects of exposure to quaternary-ammonium-based biocides on antimicrobial susceptibility and tolerance to physical stresses in bacteria from organic foods. Food Microbiology, 63, 58-71. https://doi.org/10.1016/j. fm.2016.10.037

Košmelj, K. (2007). Uporabna statistika. 2. dop. izd. Ljubljana, Biotehniška fakulteta: 239 str. http://www.bf.uni-lj.si/fileadmin/groups/2721/Uporabna_statistika_okt_2007/Uporabna_statistika_01.pdf (januar 2018)
Klančnik, A., Piskernik ,S., Jeršek, B., \& Smole Možina, S. (2010). Evaluation of diffusion and dilution methods to determine the antibacterial activity of plant extracts. Journal of Microbiological Methods, 81(2), 121-126. https://doi. org/10.1016/j.mimet.2010.02.004

Klodzinska, S. Priemel, P. A., Rades, T., \& Nielsen, H. M. (2018). Combining diagnostic methods for antimicrobial susceptibility testing - A comparative approach. Journal of Microbiological Methods, 144, 177-185. https://doi.org/10.1016/j. mimet.2017.11.010

Korsak, D., \& Szuplewska, M. (2016). Characterization of nonpathogenic Listeria species isolated from food and food processing environment. International Journal of Food Microbiology, 238, 274-280. https://doi.org/10.1016/j.ijfoodmicro.2016.08.032

Lepe, J. A., Dominguez-Herrera, J., Pachon, J., \& Aznar, J. (2013). Determining accurate vancomycin MIC values for methicillin-resistant Staphylococcus aureus by the microdilution method. Journal of Antimicrobial Chemotherapy, 69(1), 136-138. https://doi.org/10.1093/jac/dkt308

Liu, J.J., Deng, W.J., Yu, M.Q., Wen, R.Z, Yao, S.Z., \& Chen, B. (2017). Rapid analysis of benzalkonium chloride using paper spray mass spectrometry. Journal of Pharmaceutical and Biomedical Analysis, 145, 151-157. https://doi. org/10.1016/j.jpba.2017.06.030

Soumet, C., Meheust, D., Pissavin, C., Le Grandois, P., Fremaux, B., Feurer, C., Le Roux, A., Denis, M., \& Maris, P. (2016). Reduced susceptibilities to biocides and resistance to antibiotics in food-associated bacteria following exposure to quaternary ammonium compounds. Journal of Applied Microbiology, 121, 1275-1281. https://doi.org/10.1111/ jam. 13247

Soumet, C., Ragimbeau, C., \& Maris, P. (2005). Screening of benzalkonium chloride resistance in Listeria monocytoge- 
nes strains isolated during cold smoked fish production. Letters in Aplied Microbiology, 41(3), 291-296. https://doi. org/10.1111/j.1472-765X.2005.01763.x

To, M.S., Favrin, S., Romanova, N., \& Griffiths, M. W. (2002). Postadaptational resistance to benzalkonium chloride and subsequent physicochemical modifications of Listeria monocytogenes. Applied and Environmental Micro- biology, 68(11), 5258-5264. https://doi.org/10.1128/ AEM.68.11.5258-5264.2002

Wu, G., Yang, Q., Long, M., Guo, L., Li, B., Meng, Y., Zhang, A., Wang, H., Liu, S., \& Zou, L. (2015). Evaluation of agar dilution and broth microdilution methods to determine the disinfectant susceptibility. The Journal od Antibiotics, 68(11), 661-665. https://doi.org/10.1038/ja.2015.51 